\title{
ALDH1-Bright Epithelial Ovarian Cancer Cells Are Associated with CD44 Expression, Drug Resistance, and Poor Clinical Outcome
}

\author{
Yu-Chi Wang, ${ }^{\star \dagger \ddagger}$ Yi-Te Yo, ${ }^{*}$ Hsin-Yi Lee, ${ }^{\star \S}$ \\ Yu-Ping Liao, ${ }^{\star}$ Tai-Kuang Chao, ${ }^{\S}$ Po-Hsuan Su, ${ }^{*}$ \\ and Hung-Cheng Lai ${ }^{\star \dagger \neq \uparrow}$

\begin{abstract}
From the Laboratory of Epigenetics and Cancer Stem Cells," the Graduate Institute of Medical Sciences, ${ }^{\dagger}$ the Departments of Obstetrics and Gynecology, ${ }^{\ddagger}$ and Pathology, ${ }^{\S}$ and the Graduate Institute of Life Sciences, ${ }^{\text {"T }}$ Tri-Service General Hospital, National Defense Medical Center, Taipei, Taiwan, China
\end{abstract}

The role of aldehyde dehydrogenase 1 (ALDH1) as an ovarian cancer stem cell marker and its clinical significance have rarely been explored. We used an Aldefluor assay to isolate ALDH1-bright (ALDH1 ${ }^{\text {br) }}$ cells from epithelial ovarian cancer cell lines and characterized the properties of the stem cells. ALDH1 ${ }^{\text {br }}$ cells were enriched in ES-2 (1.3\%), TOV-21G (1.0\%), and CP70 (1.2\%) cells. Both ALDH1 ${ }^{\text {br }}$ and ALDH1 ${ }^{\text {low }}$ cells repopulated stem cell heterogeneity, formed spheroids, and grew into tumors in immunocompromised mice, although these processes were more efficient in ALDH1 $^{\text {br }}$ cells. In the ES-2 and CP70 cells, ALDH1 ${ }^{\text {br }}$ cells conferred more chemoresistance, and were more enriched in CD44 (by 1.74-fold and 5.18-fold, respectively) than in CD133 (by 1.39-fold and 1.17fold, respectively), compared with ALDH1 ${ }^{\text {low }}$ cells. Immunohistochemical staining for ALDH1 on a tissue microarray containing 84 epithelial ovarian cancer samples revealed that patients with higher ALDH1 expression $(>50 \%)$ had poor overall survival, compared with those with lower ALDH1 $(P=0.004)$ and yielded an odds ratio of death of $2.43(95 \% \mathrm{CI}=\mathbf{1 . 1 2}$ to 5.28) by multivariate analysis. The results did not support ALDH1 alone as an ovarian cancer stem cell marker, but demonstrated that ALDH1 is associated with CD44 expression, chemoresistance, and poor clinical outcome. The use of a combination of ALDH1 with other stem cell markers may help define ovarian cancer stem cells more stringently. (Am J Pathol 2012, 180:1159-1169; DOI: 10.1016/j.ajpath.2011.11.015)
Epithelial ovarian cancer (EOC), which represents the most lethal gynecological cancer worldwide, often produces no symptoms, and the disease is often detected at a late stage. ${ }^{1}$ EOC is a heterogeneous disease with diverse subtypes that exhibit different tumor behaviors, including morphological characteristics, clinical manifestations, and genetic backgrounds. ${ }^{2-4}$ Ovarian cancer comprises several groups of malignancies affecting the ovary. Data on the molecular and genetic alterations associated with ovarian tumorigenesis are limited. ${ }^{5}$ Given the present poor understanding of the origin of ovarian cancer, diagnosing and treating this disease constitute a major clinical challenge. Despite the high variability among subtypes of ovarian cancer, patients with this disease receive the same treatment: cytoreductive surgery, followed by platinum-based chemotherapy. Overall survival, however, remains at $30 \% .{ }^{6}$ To improve patient survival, the research focus has shifted to the individual tumor subtypes. In addition, exploration of the molecular characteristics of target therapies is needed.

The recent paradigm shift from a stochastic model to a cancer stem cell model of tumorigenesis has profound implications for ovarian cancer therapies. This cancer stem cell model suggests that a small fraction of tumor progenitors (namely, cancer-initiating cells with self-renewing properties) may be responsible for resistance to chemotherapy. ${ }^{7}$ The theoretical advantage offered by the isolation of cancer stem cells is the opportunity to develop novel drugs that target cancer stem cells effectively, with resulting clinical improvement. Various meth-

Supported by grants NHRI-EX99-9717NC (H.-C.L.) and NHRI-EX1009717NC (H.-C.L.) from National Health Research Institutes, Taiwan, and by grants TSGH-C100-010-014-S01 (M.-H.Y.) and TSGH-C100-010-014S02 (H.-C.L.) from Tri-Service General Hospital, Taiwan.

Accepted for publication November 8, 2011.

Supplemental material for this article can be found at http://ajp. amjpathol.org or at doi: 10.1016/j.ajpath.2011.11.015.

Address reprint requests to Hung-Cheng Lai, M.D., Ph.D., Department of Obstetrics and Gynecology, Tri-Service General Hospital, National Defense Medical Center, 5F, 325, Sec 2, Cheng-Gong Rd., Neihu District, Taipei City 114, Taiwan, Republic of China. E-mail: hclai@ndmctsgh. edu.tw. 
ods have been used in an attempt to isolate ovarian cancer stem cells. We have successfully characterized spheroids derived from primary ovarian cancer patients as cancer-initiating cells; these cells display distinct cell surface markers $\left(\mathrm{CD} 44^{+} / \mathrm{CD} 117^{+}\right) .{ }^{8}$ Other surface markers, including $\mathrm{CD}_{133^{+}}$and $\mathrm{CD} 44^{+} / \mathrm{Myd} 88^{+}$, are also reported as potential ovarian cancer stem cell markers. ${ }^{9,10}$ In addition, a surface marker-free dye-exclusion assay has also identified side populations and stem-like cells from ovarian cancer cell lines and human cancer tissues. ${ }^{11,12}$ Another marker-free method, using label retention of the dye PKH67/PKH26, identified quiescent ovarian cancer stem-like cells. ${ }^{13}$ These studies have revealed that ovarian cancer is a heterogeneous disease. None of these markers are satisfactory for the identification of ovarian cancer stem cells.

Aldehyde dehydrogenase (ALDH) is a detoxifying enzyme responsible for oxidation of intracellular aldehyde; it also protects organisms from harmful aldehydes and cytotoxic drugs. ${ }^{14,15}$ In 1995, Jones et $\mathrm{al}^{16}{ }^{16}$ reported that the intracellular ALDH isoform 1 (ALDH1) can be used to isolate human hematopoietic stem cells and leukemic stem cells. ALDH1 has been used to identify normal stem or progenitor cells in various tissues. ${ }^{17,18}$ Recently, ALDH1-bright $\left(\mathrm{ALDH} 1^{\mathrm{br}}\right)$ cells were reported to possess cancer stem-cell properties in various types of solid tumors, including breast, colon, prostate, and lung tumors. ${ }^{19-22}$ Reports on the properties of subpopulations of $\mathrm{ALDH} 1^{\text {br }}$ ovarian cancer cells are rare. ${ }^{23}$ The role of ALDH1 expressing in human ovarian cancer remains elusive. To date, investigation of this issue has yielded conflicting results. ${ }^{23-27}$

The purpose of the present study was to explore the potential stem-cell-like properties of $A L D H 1{ }^{\text {br }}$ cells in ovarian cancer cell lines and to test the clinical significance of ALDH1 expression in tumor tissues.

\section{Materials and Methods}

\section{Cell Lines}

SKOV-3, OVCAR-3, A2780, and CP70 cells were maintained in RPMI-1640 medium (Gibco, Rockville, MD). TOV-21G cells were maintained in culture using MCDB 105 (Sigma-Aldrich, St. Louis, MO)/Medium 199 (Gibco) (1:1). ES-2 cells were maintained in McCoy's 5A medium (Invitrogen-Life Technologies, Carlsbad, CA). All media were supplemented with $10 \%$ fetal bovine serum (Invitrogen) and $100 \mathrm{IU} / \mathrm{mL}$ of penicillin-streptomycin at $37^{\circ} \mathrm{C}$ under a humidified atmosphere containing $5 \% \mathrm{CO}_{2}$.

\section{Aldefluor Assay and FACSAria Sorting}

An Aldefluor kit (StemCell Technologies, Vancouver, BC, Canada; Tukwila, WA) was used to assess ALDH activity in the EOC cell lines. Briefly, cells were incubated in Aldefluor buffer containing ALDH substrate $(1 \mu \mathrm{mol} / \mathrm{L}$ per $1 \times 10^{6}$ cells) and incubated for 30 minutes at $37^{\circ} \mathrm{C}$. One sample was treated with $50 \mathrm{mmol}$ of diethylaminobenzaldehyde (DEAB, an ALDH inhibitor), as a negative control. After incubation, cells were washed once with Hank's buffered saline solution (BioWhittaker, Walkersville, MD) and were resuspended in Hank's buffered saline solution supplemented with $5 \%$ fetal bovine serum. Cells were stained with $1 \mu \mathrm{g} / \mathrm{mL}$ of propidium iodide (Sigma-Aldrich), to assess viability and were then analyzed and sorted using flow cytometry on a FACSAria instrument (BD Biosciences, San Jose, CA). Accudrop beads (BD Biosciences) were used to confirm the purity of the FACS separation.

\section{Spheroid Culture}

Spheroid culturing was performed as described by Ponti et al..$^{28}$ Cells from FACSAria sorting in the primary culture were plated immediately in ultralow attachment plates (Corning Life Sciences, Acton, MA) at a density of 2000 viable cells per milliliter in serum-free DMEM/F12 medium containing $5 \mathrm{mg}$ insulin (Sigma-Aldrich), 0.4\% bovine serum albumin (Sigma-Aldrich), $10 \mathrm{ng} / \mathrm{mL}$ basic fibroblast growth factor (Invitrogen), and $20 \mathrm{ng} / \mathrm{mL}$ human recombinant epidermal growth factor (Invitrogen) until the growth of spheres. Single cells were prepared using dissociation, both mechanically and with dissociation using Accutase (Millipore, Billerica, MA) in $0.5 \mu \mathrm{mol} / \mathrm{L}$ EDTA (Millipore), on day 4. At the next passage, cells were plated in six-well ultralow attachment plates (Corning) for 7 days and then were photographed. We assessed the size of spheroids based on images captured using a cooled, back-thinned CCD camera; images were analyzed using Image-Pro Plus 6.0 software (Media Cybernetics, Bethesda, MD), which provides a computational algorithm for the analysis of cellular areas. We set the threshold for image capture at a size of 2000 pixels.

\section{Tumorigenic Assay}

NOD-SCID mice were purchased from the National Taiwan University. TOV-21G ALDH1 ${ }^{\text {br }}$ cells (suspended in $50 \mu \mathrm{L}$ of Matrigel) and TOV-21G ALDH1 ${ }^{\text {low }}$ cells (suspended in $50 \mu \mathrm{L}$ of PBS) were injected subcutaneously into the hind leg of NOD-SCID mice with different numbers of $10^{5}, 10^{4}$, and $10^{3}$ cells. Once xenografts were established, the size of the tumors in the mice was measured once a week; tumor volume was calculated as $0.5236 \times L_{1} \times\left(L_{2}\right)^{2}$, where $L_{1}$ is the length of the long axis and $L_{2}$ is the length of the short axis of the tumor. ${ }^{29}$ The mice were sacrificed after 6 to 9 weeks, and tumors were analyzed for the presence of outgrowth.

All animal studies were approved by the Institutional Animal Care and Use Committee of the National Defense Medical Centre, Taipei, Taiwan.

\section{Cell Viability Assay}

Cells were plated at 1000 cells per 96-well plate for 1 day and then were treated with chemotherapeutic drugs for 72 hours. Subsequently, we evaluated cell viability using the CellTiter-Glo (Promega, Annandale, NSW, Australia) luminescent cell-viability assay (ATP assay). Briefly, the ATP reagent $(0.01 \mu \mathrm{mol} / \mathrm{L})$ was added to $100 \mu \mathrm{L}$ of medium containing cells in each well of a 96-well plate, and 


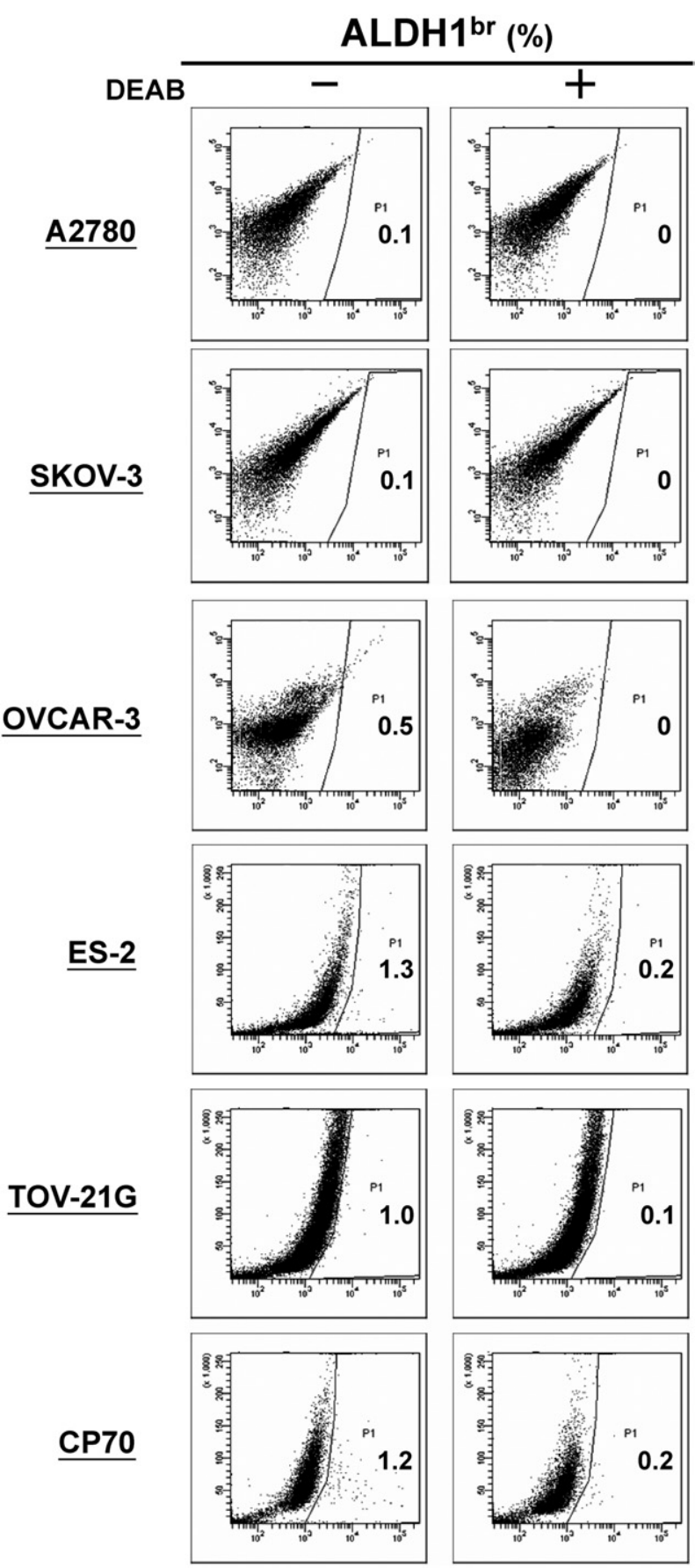

Figure 1. ALDH1 enzymatic activity in six EOC cell lines. DEAB, a specific inhibitor of ALDH1, was used for confirmation of gating areas.

the intensity of luminescence was measured 10 minutes after the addition of the reagent.

\section{Flow Cytometry Analysis}

The expression of cell markers was evaluated in $\mathrm{ALDH} 1^{\text {br }}$ and $\mathrm{ALDH} 1^{\text {low }}$ cells derived from ES-2 and CP70 cells using a FACSCalibur apparatus (BD Biosciences). The antiCD133 antibody was purchased from Abcam (Cambridge, UK) and was indirectly conjugated with fluorescence com- pound. Nonconfluent cultures were trypsinized into a singlecell suspension and washed with PBS. Cells were incubated with the appropriate antibodies at room temperature for 30 minutes, washed, and incubated with fluorescein isothiocyanate-conjugated secondary antibodies for 20 minutes. Mouse anti-human CD44-PE antibody was purchased from BioLegend (San Diego, CA). Nonconfluent cultures were trypsinized into a single-cell suspension and washed with PBS. Cells were stained with $1 \mu \mathrm{g} / \mathrm{mL}$ of propidium iodide (SigmaAldrich), to assess viability, and were then analyzed using a FACSCalibur apparatus (BD Biosciences).

\section{Tissue Microarray}

Paraffin-embedded tumor tissues were retrieved from the Department of Pathology, National Defense Medical Center, Taipei, Taiwan, and tissue microarray slides were prepared. The tissue microarrays consisted of 84 ovarian surface epithelial carcinomas: 61 serous cystadenocarcinomas, 14 mucinous cystadenocarcinomas, 3 endometrioid adenocarcinomas, and 6 clear cell carcinomas. For the present study, two pathologists (T.-K. Chao and C.-K. Lin) screened the histological sections and selected areas of representative tumor cells. One tissue core (2 $\mathrm{mm}$ in diameter) was taken from each of the

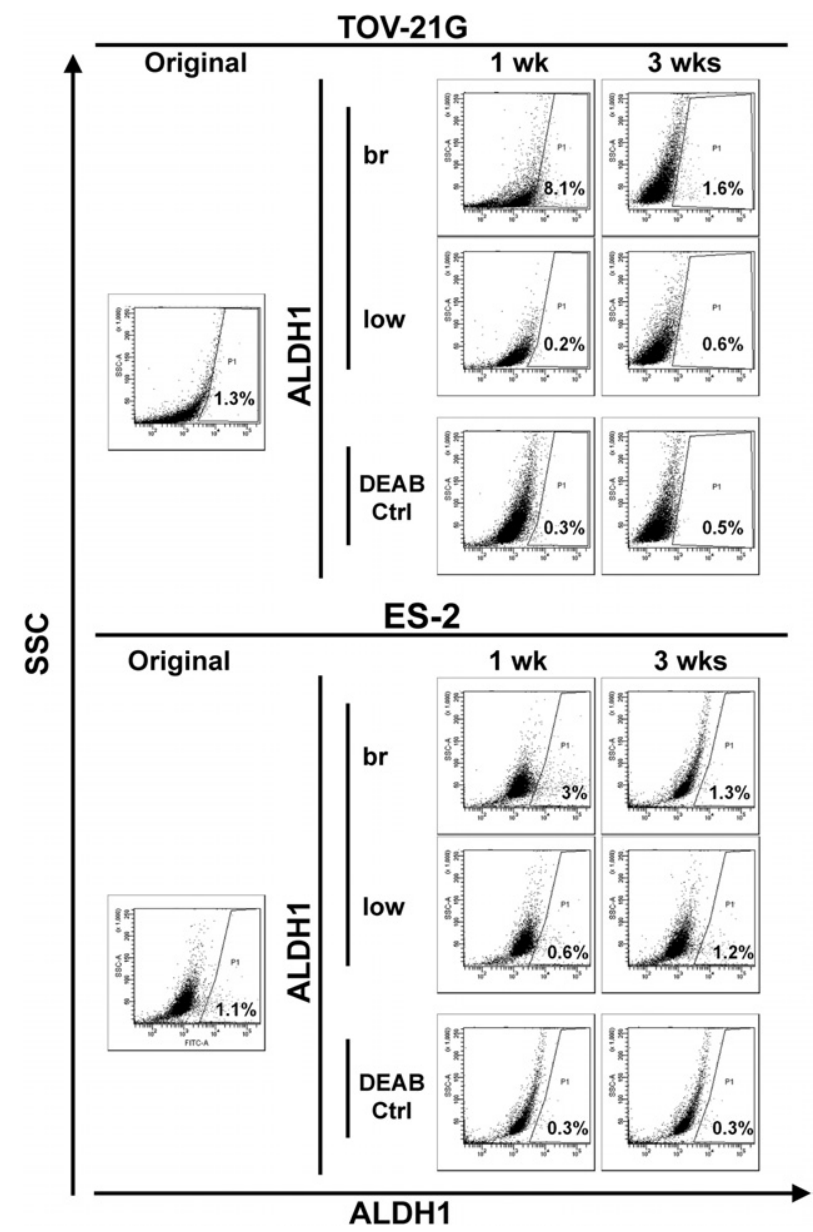

Figure 2. Repopulation of ALDH $1^{\text {br }}$ and ALDH $1^{\text {low }}$ cells. DEAB was used in each sorting round to confirm the gating area. SSC, side scatter. 


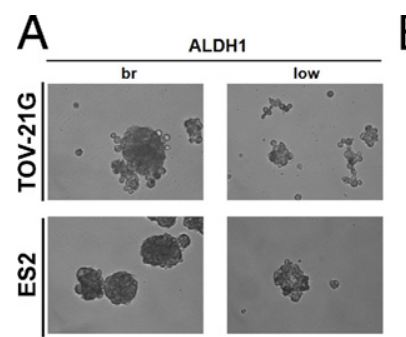

B
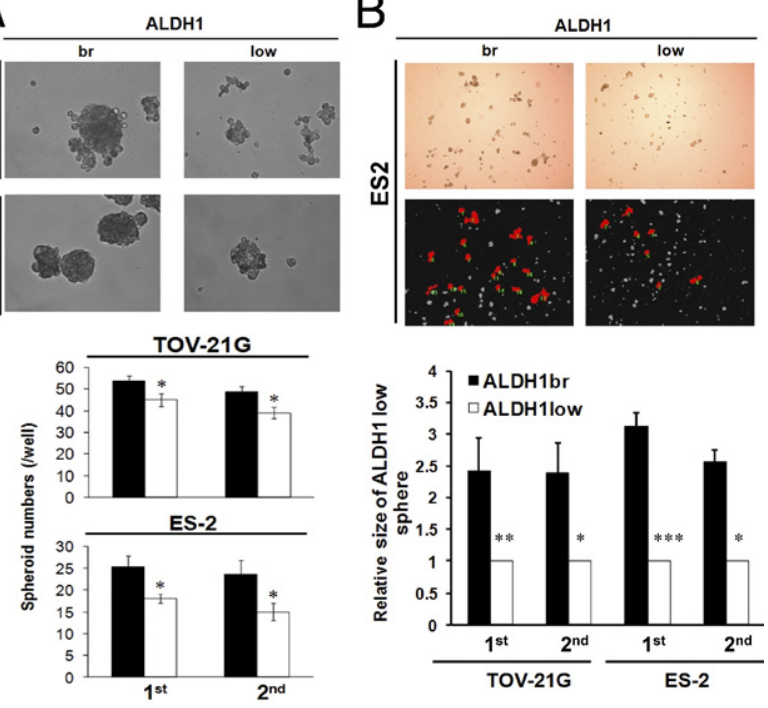

C

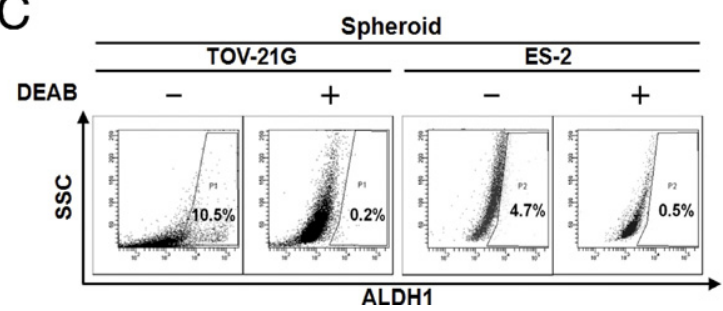

Figure 3. Spheroid formation capacity of $\mathrm{ALDH} 1^{\mathrm{br}}$ and $\mathrm{ALDH} 1^{\text {low }}$ cells. A: Typical morphology (top) and number (bottom) of spheroids in ALDH $1^{\text {br }}$ and ALDH1 $1^{\text {low }}$ cells in TOV-21G and ES-2 EOC cell lines. ALDH1 ${ }^{\text {br }}$ cells generated significantly larger and more spheroids, compared with ALDH1 ${ }^{\text {low }}$ subpopulations. Original magnification, $\times 200$. The number of spheroids after serial passages reflects the self-renewal capability of these cells in vitro. $* P<0.05$. B: The relative spheroid area derived from ALDH1 ${ }^{\text {br }}$ and ALDH1 ${ }^{\text {low }}$ cells was analyzed using Media Cybernetics Image-Pro Plus 6.0 software in TOV-21G and ES-2 cell lines. Images are at original magnification of $\times 50 . * P<0.05, * * P<0.01$, and $* * * P<0.001$. C: Enrichment of $\mathrm{ALDH} 1^{\mathrm{br}}$ cells in spheroids. SSC, side scatter.

representative tumor samples and placed in a new recipient paraffin block. Pathological data corresponding to each specimen examined, which were collected using an Institutional Review Board-approved protocol, were analyzed.

\section{Immunohistochemistry}

Tissue microarray sections were dewaxed in xylene, rehydrated in alcohol, and immersed in 3\% hydrogen peroxide for 10 minutes to suppress endogenous peroxidase activity. Antigen retrieval was performed by heating each section at $100^{\circ} \mathrm{C}$ for 30 minutes in $0.01 \mathrm{~mol} / \mathrm{L}$ sodium citrate buffer ( $\mathrm{pH}$ 6.0). After three 5-minute rinses in PBS, sections were incubated for 1 hour at room temperature with a mouse monoclonal anti-human ALDH1 antibody (clone 44/ALDH, 1:100; BD Biosciences) diluted in PBS. After three 5-minute washes in PBS, sections were incubated with horseradish-peroxidase-labeled rabbit anti-mouse immunoglobulin (Dako, Carpinteria, CA) for 1 hour at room temperature. After three additional washes, peroxidase activity was visualized using a solution of diaminobenzidine at room temperature.
For evaluation of immunoreactivity and histological appearance, all tissue microarray slides were examined and scored by two pathologists (T.-K. Chao and C.-K. Lin) concurrently. The cytoplasmic immunostaining of ALDH1 in individual tumor cells was classified as $0 \%$ to $50 \%$ positive ALDH1 cells or $>50 \%$ positive ALDH1 cells. As a negative control, the primary antibody was replaced with nonimmune serum.

\section{Statistical Analysis}

An SPSS software package (version 13 for Windows; SPSS, Chicago, IL) was used for statistical analysis. All values are expressed as means \pm SEM. The Mann-Whitney $U$-test was used to compare cell proliferation, and the Student's $t$-test was used to compare the spheroid formation efficiency. The $\chi^{2}$ test or Fisher's exact test was used to identify correlations between ALDH1 expression and clinicopathological characteristics. Disease-free interval and overall survival time were assessed by Cox regression analysis. Kaplan-Meier survival curves were compared using the log rank test. The significance level was defined as $P<0.05$.

A

$\mathrm{B}$
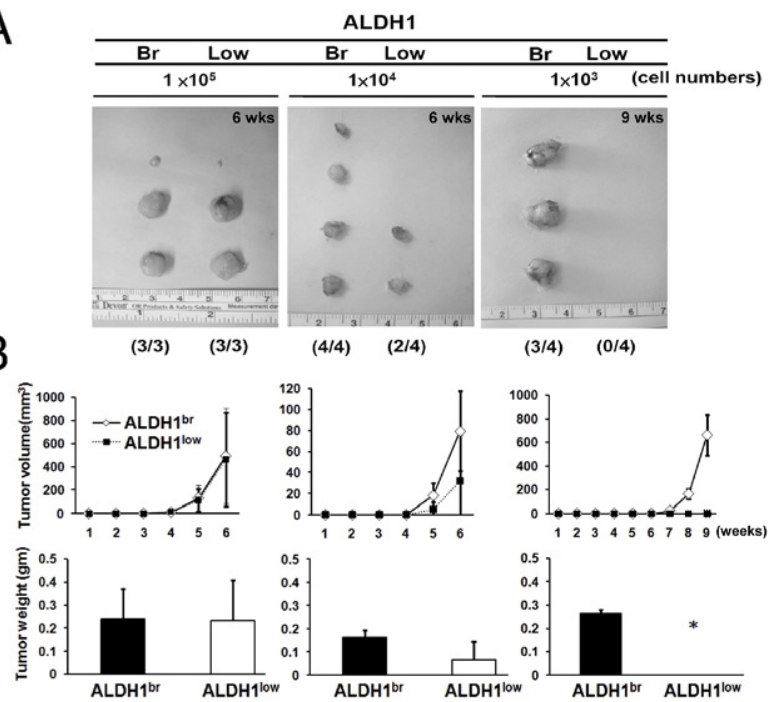

$\mathrm{C}$

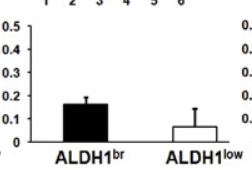

ALDH1 ${ }^{\text {br }}$ ALDH1 $1^{\text {low }}$

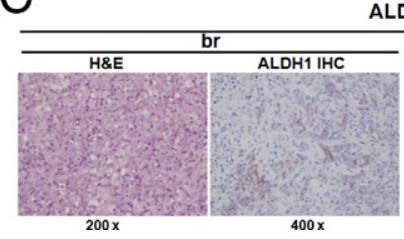

ALDH1

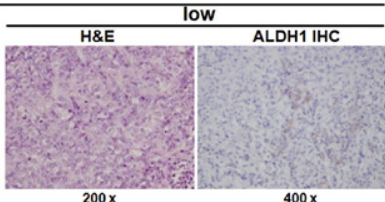

Figure 4. Tumorigenicity of ALDH1 $1^{\text {br }}$ and ALDH1 $1^{\text {low }}$ cells. A: ALDH1 $1^{\text {br }}$ and ALDH1 ${ }^{\text {low }}$ cells were injected into each side of a mouse. B: Tumor growth curves and tumor weight were plotted for different numbers of TOV-21G cells injected $\left[100,000\right.$ (left), 10,000 (middle), and 1000 (right) cells] for each ALDH1 ${ }^{\text {br }}$ and ALDH1 ${ }^{\text {low }}$ population. $* P<0.05$. C: H\&E staining of tumors derived from ALDH1 ${ }^{\text {br }}$ and ALDH1 ${ }^{\text {low }}$ cells (original magnification, $\times 200$ ) and immunohistochemical staining of ALDH1 expression (original magnification, $\times 400$ ). 


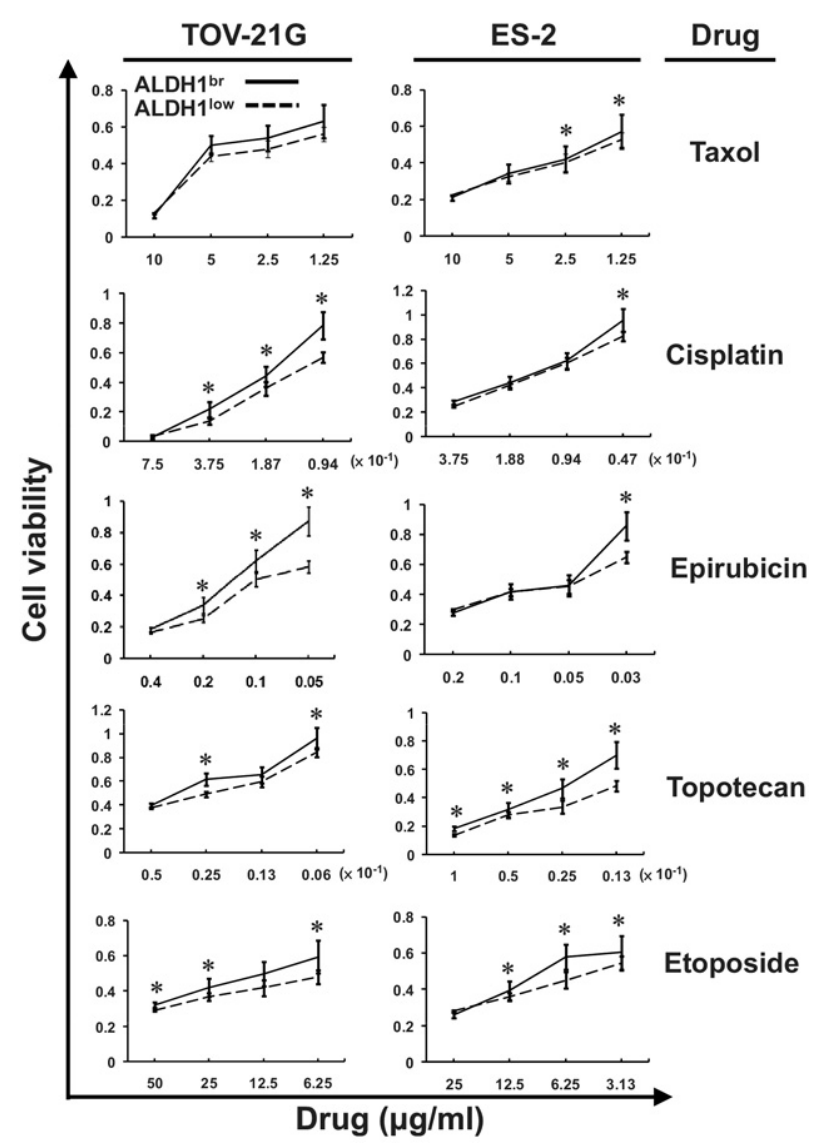

Figure 5. Comparison of drug sensitivity between ALDH1 $1^{\text {br }}$ and ALDH1 ${ }^{\text {low }}$ cells All tests were performed in two biologically independent studies, with triplicate trials for every experiment. Data are expressed as means \pm SE. ${ }^{*} P<0.05$.

\section{Results}

\section{Subpopulations of $A L D H 1^{\text {br }}$ Cells in EOC Cell Lines}

To examine ALDH1 enzymatic activity in ovarian cancers, we analyzed $\mathrm{ALDH} 1^{\text {br }}$ cells in human ovarian cancer cell lines using an Aldefluor assay (StemCell Technologies) and flow cytometry (FACSAria; BD Biosciences). Cells were re-sorted using Accudrop beads (BD Biosciences; one drop of beads in $1 \mathrm{~mL}$ of PBS) as a positive control. The purity detected in our experiments was $96.3 \%$ (see Supplemental Figure S1 at $h$ ttp://ajp.amjpathol.org). Activity of ALDH1 varied considerably among cell lines (Figure 1). ALDH1 $1^{\text {br }}$ cells were enriched in two clear cell carcinoma cell lines, TOV-21G (1\%) and ES-2 (0.8\%), and in a drug-resistant subclone (CP70; $2.8 \%$ ) derived from A2780 (serous type), but not in parental A2780 or other serous-type cancers (SKOV-3 and OVCAR-3). TOV-21G and ES-2 cells were therefore chosen for further studies.

\section{Comparison of Repopulation Capability between $A L D H 1^{\text {br }}$ and ALDH1 ${ }^{\text {low }}$ Cells}

The repopulation ability of $\mathrm{ALDH} 1^{\text {br }}$ cells in vitro was analyzed, to test their stem-like self-renewal properties.
$\mathrm{ALDH} 1^{\text {br }}$ cells were assessed using an Aldefluor assay 1 week and 3 weeks later. The proportion of $A L D H 1{ }^{\text {br }}$ cells in TOV-21G and ES-2 cell populations decreased with passages, indicating that $\mathrm{ALDH} 1^{\text {br }}$ cells can rapidly generate $\mathrm{ALDH}_{1}$ low populations (Figure 2). The ALDH1 $1^{\text {br }}$ cells of TOV-21G and ES-2 can complete their repopulation in 3 weeks, at which time the proportions of ALDH $1^{\text {br }}$ cells had returned to the original percentages. In addition, $\mathrm{ALDH} 1^{\text {low }}$ cells also seemed to be able to generate ALDH $1^{\text {br }}$ cells. Of note, in 3 weeks the ALDH $1^{\text {low }}$ cells of ES-2 cells repopulated their ALDH1 $1^{\text {br }}$ cells. TOV-21G ALDH $1^{\text {low }}$ cells generated $0.6 \%$ of $A L D H 1^{\text {br }}$ cells in 3 weeks, which is about one half of its original proportion. Our results suggest that both $\mathrm{ALDH} 1^{\mathrm{br}}$ and $\mathrm{ALDH} 1^{\text {low }}$ cells retain their repopulation potential. ALDH1 $1^{\text {br }}$ cells may give rise to $\mathrm{ALDH} 1^{\text {low }}$ cells more efficiently, whereas the opposite conversion was compromised in some cells.

\section{Comparison of Spheroid-Formation Capacity between ALDH1 $1^{\text {br }}$ and ALDH1 $1^{\text {low }}$ Cells}

To test the stem-like property further, we characterized the spheroid-formation ability of $\mathrm{ALDH} 1^{\mathrm{br}}$ and $\mathrm{ALDH} 1^{\text {low }}$ cells. ALDH1 $1^{\text {br }}$ and ALDH1 $1^{\text {low }}$ cells derived from TOV$21 \mathrm{G}$ and ES-2 cells were cultured in serum-free suspension culture at a density of $10^{4}$ cells per well (2000 cells $/ \mathrm{mL}$ ) in six-well plates. Spheroid formation was assessed at day 7. ALDH1 $1^{\text {br }}$ cells showed a high capacity for spheroid formation, regarding size and num-

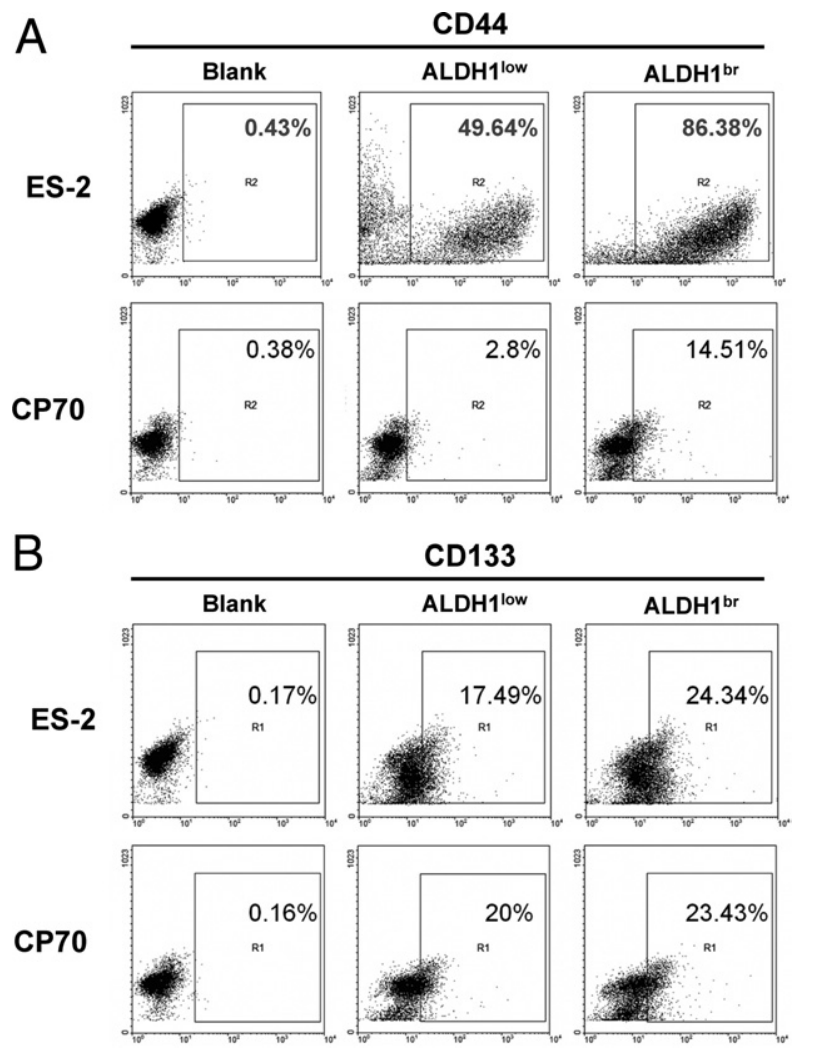

Figure 6. Relationship between ALDH1 and CD 44/CD133. ALDH1 $1^{\text {br }}$ and ALDH $1^{\text {low }}$ cells were sorted and analyzed for expression of CD44 (A) and CD133 (B). CD $44^{+}$and CD $133^{+}$gates were defined by an isotypic control. 


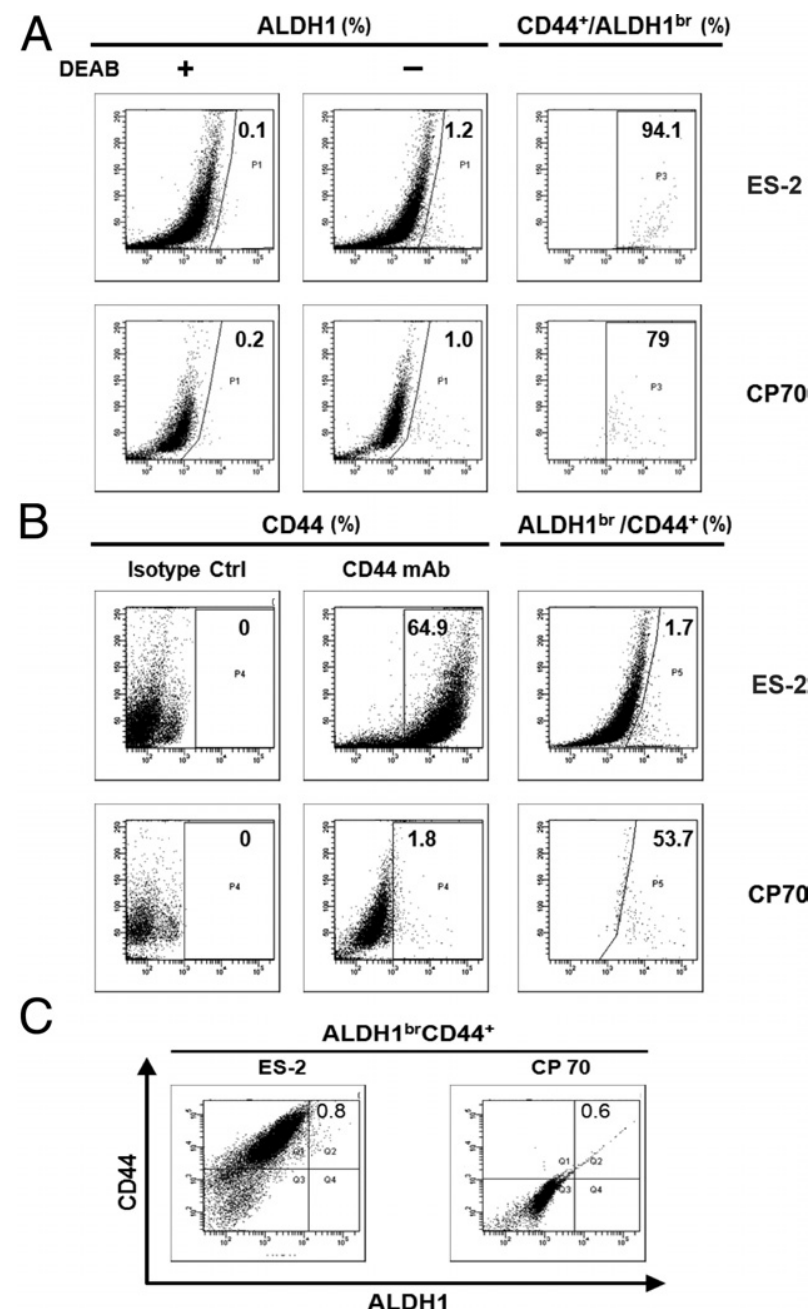

Figure 7. $\mathrm{ALDH} 1^{\mathrm{br}} / \mathrm{CD} 44^{+}$cells in ovarian cancer cell lines. A: $\mathrm{CD} 44^{+}$in ALDH1 ${ }^{\text {br }}$ cells. B: ALDH1 ${ }^{\text {br }}$ cells in $\mathrm{CD}_{4} 4^{+}$cells. C: Cells costained with anti-CD $44 \mathrm{PE}$ monoclonal antibody $(\mathrm{mAb})$ and Aldefluor. The gating area was defined by an isotypic control and DEAB.

bers (Figure 3, A and B), and for self-renewal, as assessed using serial passages (Figure 3A). In addition, $\mathrm{ALDH} 1^{\mathrm{br}}$ cells were further enriched in spheroids: $10.5 \%$ of TOV-21G and $4.7 \%$ of ES-2 spheroids were ALDH1 $1^{\text {br }}$ cells (Figure $3 \mathrm{C}$ ).

\section{Tumorigenicity of $\mathrm{ALDH} 1^{\text {br }}$ and $\mathrm{ALDH} 1^{\text {low }}$ Cells}

To test the effects of ALDH1 on tumorigenicity, we established a xenograft tumor-formation assay using NODSCID mice. ALDH1 $1^{\text {br }}$ cells exhibited tumorigenic potential at a density as low as $10^{3}$ cells. No mice injected with an equivalent amount of $\mathrm{ALDH} 1^{\text {low }}$ cells grew tumors (Figure $4 \mathrm{~A})$. After the injection of $10^{4}$ cells, all ALDH1 $1^{\text {br }}$ and half of the ALDH1 $1^{\text {low }}$ cells grew tumors. The weekly growth curves of tumor volume at different weeks and tumor weight after implantation are shown in Figure 4B. Tumor weight was significantly greater in $\mathrm{ALDH} 1^{\mathrm{br}}$ cells $\left(10^{3}\right.$ cells injected), compared with ALDH1 ${ }^{\text {low }}$ cells $(P=$ 0.0319). Histopathology confirmed that these were human ovarian tumors (Figure 4C). The expression of
ALDH1 in these tumors was assessed using immunohistochemical staining. ALDH1 expression was identified in tumors derived from both ALDH1 $1^{\text {br }}$ and ALDH1 $1^{\text {low }}$ cells. We photographed high-power fields $(\times 400)$ randomly in each section. There was a trend for increased expression of ALDH1 in cells of ALDH1 $1^{\text {br }}$-derived tumors, compared with those of $\mathrm{ALDH}^{\text {low }}$-derived tumors (Figure $4 \mathrm{C}$ ). These results demonstrate that $\mathrm{ALDH} 1^{\text {br }}$ cells have higher tumorigenicity, compared with ALDH1 $1^{\text {low }}$ cells.

\section{ALDH1 ${ }^{\text {br }}$ Cells Are Resistant to Chemotherapeutic Drugs}

The effects of ALDH1 expression on the sensitivity to chemotherapeutic drugs were investigated. ALDH1 $1^{\text {br }}$ and ALDH1 $1^{\text {low }}$ cells were incubated with increasing con-
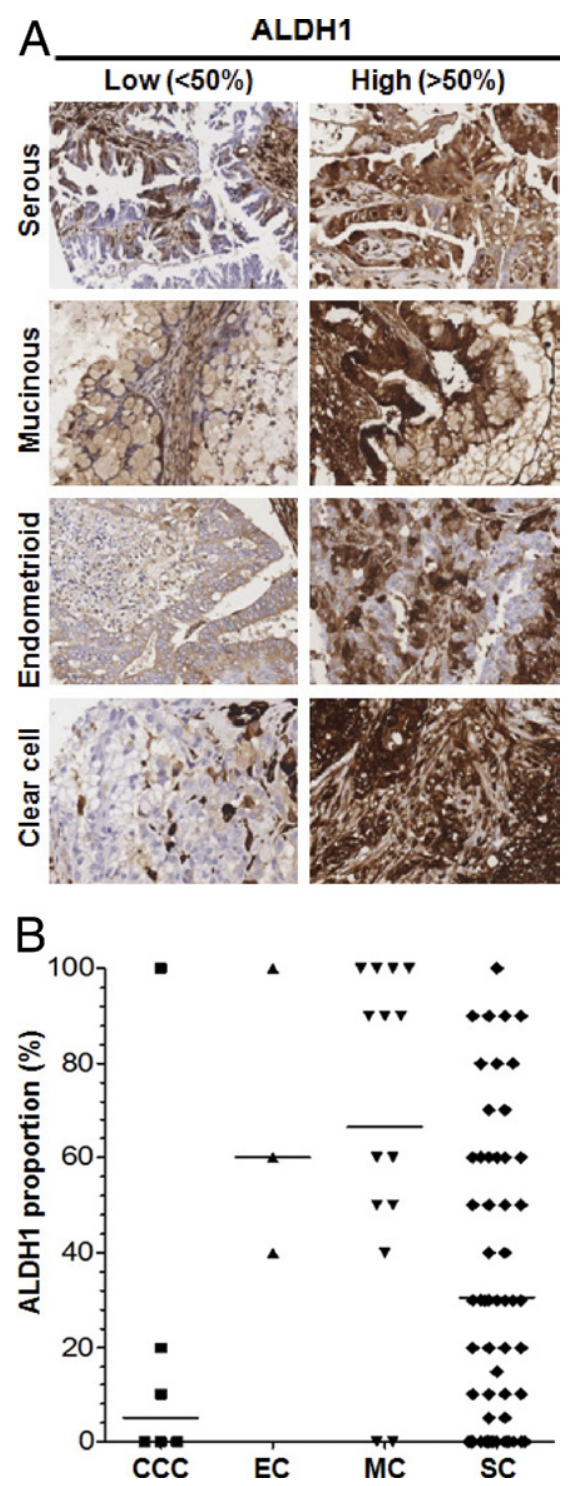

Figure 8. Expression and distribution of ALDH1 in four histological types of EOC: clear cell carcinoma (CCC), endometrioid carcinoma (EC), mucinous carcinoma (MC), and serous carcinoma (SC). A: Representative differential ALDH1 expression. B: Proportion of ALDH1 expression in cells of the different histological types. 
Table 1. Clinicopathological Features

\begin{tabular}{|c|c|c|c|}
\hline \multirow[b]{2}{*}{ Characteristic } & \multicolumn{2}{|c|}{ ALDH1 positivity } & \multirow[b]{2}{*}{$P$ value } \\
\hline & $0 \%$ to $50 \%$ & $>50 \%$ & \\
\hline Patients (no.) & 56 & 28 & \\
\hline Age (years) & & & 0.14 \\
\hline Range & $16-79$ & $29-81$ & \\
\hline Mean \pm SEM & $52.0 \pm 1.9$ & $57.0 \pm 2.8$ & \\
\hline Stage $[$ no. $(\%)]$ & & & 0.46 \\
\hline I, || & $20(74.1)$ & $7(25.9)$ & \\
\hline III, IV & $36(63.2)$ & $21(36.8)$ & \\
\hline Nuclear grade [no. (\%)] & & & 0.50 \\
\hline G1 & $9(69.2)$ & $4(30.8)$ & \\
\hline G2 & $22(59.5)$ & $15(40.5)$ & \\
\hline G3 & $25(73.5)$ & $9(26.5)$ & \\
\hline Histological type [no. (\%)] & & & $0.01^{* \dagger}$ \\
\hline Serous type & $45(73.8)$ & $16(26.2)$ & \\
\hline Mucinous type & $5(35.7)$ & $9(64.3)$ & \\
\hline Endometrioid type & $1(33.3)$ & $2(66.7)$ & \\
\hline Clear cell type & $5(83.3)$ & $1(16.7)$ & \\
\hline Histological type [no. (\%)] & & & $0.04^{*}$ \\
\hline Serous type & $45(73.8)$ & $16(26.2)$ & \\
\hline Other types & $11(47.8)$ & $12(52.2)$ & \\
\hline
\end{tabular}

${ }^{*} P<0.05$.

${ }^{\dagger}$ Fisher's exact test.

centrations of various chemotherapeutic agents (taxol, cisplatin, epirubicin, topotecan, and etoposide). In general, ALDH1 $1^{\text {br }}$ cells showed mild but significant resistance to these agents, which are commonly used in clinical practice (Figure 5). Although minor, these differences were significant in general. Specifically, the difference in cell viability was $>20 \%$ at a low dose of epirubicin in both cell lines tested. TOV-21G cells, which exhibited higher ALDH1 activity, were more resistant to cisplatin, whereas ES-2 cells were more resistant to topotecan. There was no significant difference in chemosensitivity to taxol, which stabilizes microtubules. This suggests that $\mathrm{ALDH} 1^{\mathrm{br}}$ populations are more resistant to chemotherapeutic drugs.

\section{ALDH1 ${ }^{\text {br }}$ Cells Are Associated with the Surface Marker CD44}

Although ALDH $1^{\text {br }}$ cells are superior to $A L D H 1^{\text {low }}$ cells regarding repopulation ability, spheroid formation, chemoresistance, and tumorigenicity, ALDH ${ }^{\text {low }}$ cells also exhibit these properties, at lower efficiency. We hypothesized that $\mathrm{ALDH} 1^{\mathrm{br}}$ cells are associated with other stem cell markers, an association that renders these cells more stem-like than ALDH1 $1^{\text {low }}$ cells. We investigated the expression of CD44 and CD133 in relation to ALDH1 activity in ovarian cancer. To exploit the association of ALDH1 with stem cell markers in clear cell and serous ovarian carcinoma, the ALDH $1^{\text {br }}$ and $\mathrm{ALDH} 1^{\text {low }}$ cells from ES-2 and CP70 cell lines were analyzed for the expression of CD44 and CD133 using flow cytometry. The results showed that, relative to ALDH $1^{\text {low }}$ cells, $A L D H 1^{\text {br }}$ cells were more enriched in CD44 (by 1.74-fold and 5.18-fold for ES-2 and CP70, respectively) (Figure 6A) than in CD133 (by 1.39-fold and 1.17-fold for ES-2 and CP70, respectively) (Figure
6B). ES-2 and CP70 ALDH1 ${ }^{\text {br }}$ cells also expressed CD 44 , at $94 \%$ and $79 \%$, respectively (Figure $7 A$ ). In contrast, only $1.7 \%$ of CD $44^{+}$ES-2 cells and $53.7 \%$ of $\mathrm{CD} 44^{+} \mathrm{CP} 70$ cells exhibited high ALDH1 activity (Figure $7 \mathrm{~B}) . \mathrm{CD} 44^{+} \mathrm{ALDH} 1^{\text {br }}$ cells were rare subpopulations $(<1 \%)$ in both cell lines (Figure $7 \mathrm{C}$ ). Our results support the hypothesis that ALDH1 $1^{\text {br }}$ is associated with CD44 in ovarian cancer.

\section{Correlations between ALDH1 Protein Expression and Clinicopathological Parameters}

To verify the role of ALDH1 in ovarian cancer, we performed an immunohistochemistry analysis using ovarian cancer tissue arrays. The expression of ALDH1 varied substantially, from no expression to strong expression. For comparison, patients were classified into two groups, according to the proportion of ALDH1 expression in tumors: ALDH1 high (> 50\%) and ALDH1 low $(<50 \%)$ (Figure $8 A)$. The expression of ALDH1 was significantly associated with histological type $(P=0.01)$ (Figure 8B and Table 1). There were no significant associations between ALDH1 expression and age, stage, or nuclear grade. Patients with higher ALDH1 expression had poor overall survival, compared with those with lower ALDH1 (Figure 9A) $(P=0.004)$. A subanalysis focusing on high-grade serous carcinoma yielded consistent results (see Supplemental Figure S2 at $h t t p: / / a j p . a m j p a t h o l . o r g)$. The multivariate analysis revealed that higher ALDH1 levels conferred an odds ratio of death of $2.43(95 \% \mathrm{Cl}=1.12$ to 5.28$)$ (Table 2). There was a trend toward higher recurrence in patients with higher ALDH1 expression; however, this result did not reach significance (Figure 9B). 
A
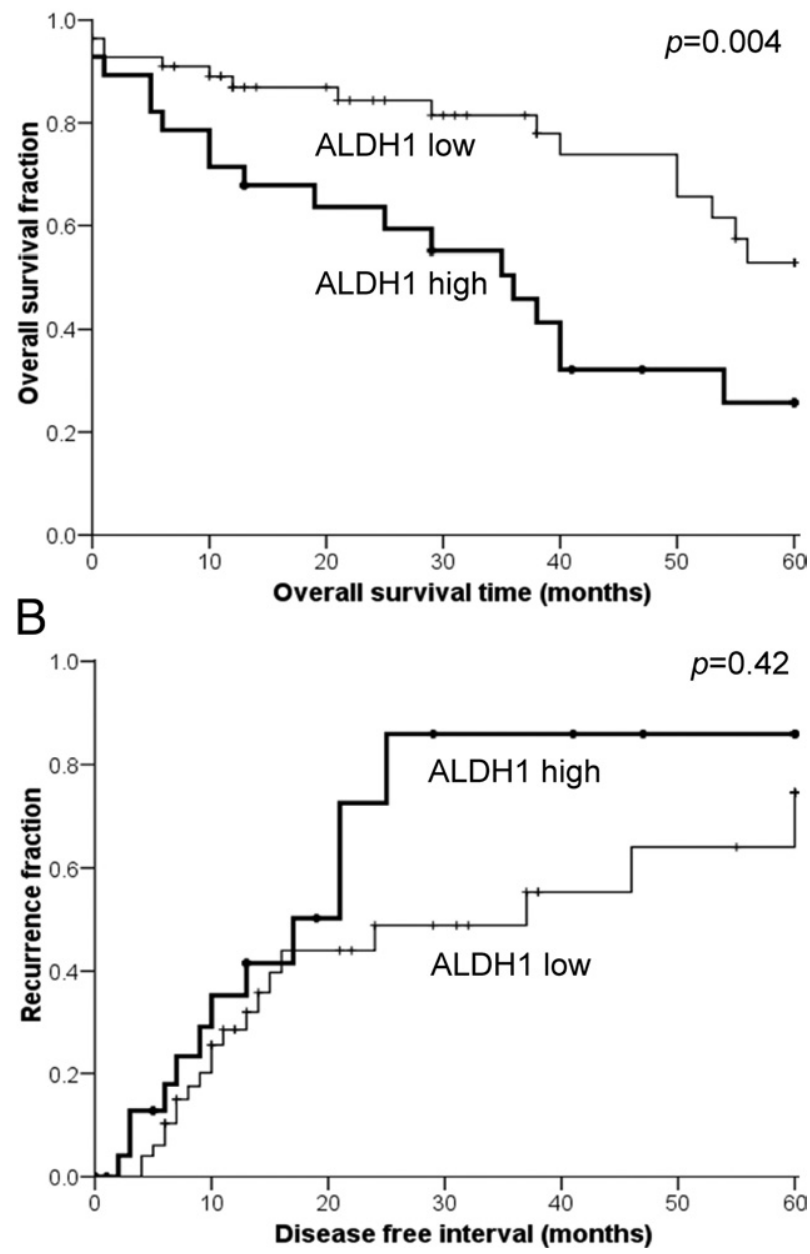

Figure 9. Kaplan-Meier analysis of overall survival (A) and recurrence $(\mathbf{B})$ in ovarian cancer patients stratified according to ALDH1 expression $(n=84)$

\section{Discussion}

ALDH1 activity, as assessed using an Aldefluor assay, provides a method for the isolation of normal and malignant progenitor cells. ${ }^{17,19}$ A previous study demonstrated that ALDH $1^{\text {br }}$ tumor cells have cancer stem-cell properties, such as self-renewal and tumorigenicity. ${ }^{19}$ Although recent reports suggest that ALDH1 is a stem cell marker in ovarian cancer of serous type, the stemlike role of the subpopulation of $A L D H 1^{\text {br }}$ cells in EOC remains to be determined. ${ }^{24,26,30}$ In the present study, we isolated $\mathrm{ALDH} 1^{\mathrm{br}}$ cells from ovarian cancer cell lines. Both $A L D H 1^{\text {br }}$ and $A L D H 1^{\text {low }}$ cells were able to form tumor spheres, repopulate heterogeneous cancer cells, and grow tumors in mice, although at different efficiencies, suggesting that ALDH1 is not a sufficient marker of ovarian cancer stem cells. However, ALDH $1^{\text {br }}$ cells conferred more stem-like properties than did ALDH1 $1^{\text {low }}$ cells, which may be due to the enrichment of CD44 and CD133 surface markers in ALDH1 $1^{\text {br }}$ cells. Recent studies indicate that the $\mathrm{ALDH} 1^{+} / \mathrm{CD} 133^{+}$status may define ovarian cancer stem cells. ${ }^{23,31} \mathrm{CD} 133^{+}$might be an upstream of $\mathrm{CD} 133^{-}$cells.
However, $\mathrm{ALDH} 1^{-} \mathrm{CD} 133^{+}$cells can generate all $\mathrm{ALDH} 1^{-/+} \mathrm{CD} 133^{+/-}$cells, ${ }^{23}$ which is consistent with our finding that $A L D H 1^{\text {low }}$ can generate both $A L D H 11^{\text {low }}$ and $\mathrm{ALDH}{ }^{\mathrm{br}}$ cells. The reason for this repopulation has not been clarified.

Our previous study showed that the $\mathrm{CD} 44^{+} / \mathrm{CD} 117^{+}$ status is a marker of ovarian cancer-initiating cells. ${ }^{8}$ The present study demonstrated further the association between elevated ALDH1 activity and CD44 in ovarian cancer. Taken together, these results suggest that ALDH1 alone is not sufficient as a marker of ovarian cancer stem cells, even though ALDH $1^{\text {br }}$ cells enriched more cancer cells with stem-cell properties, compared with ALDH1 $1^{\text {low }}$ cells. Given the heterogeneity of ovarian tumors, higher ALDH1 activity combined with other stem cell markers, such as CD44 and CD133, may define different sets of ovarian cancer stem cells.

The present study demonstrated that ALDH1 confers chemoresistance. Resistance to chemotherapy is a common phenomenon that results in disease progression, and current second-line therapies have not been proven effective regarding overall survival. ${ }^{32}$ Recent studies indicate that high ALDH1 expression is associated with chemoresistance in breast cancers. ${ }^{33,34}$ ALDH1 subpopulations were reported as associated with chemoresistance in serous-type ovarian cancer. ${ }^{24,26}$ The present study showed that ALDH1 ${ }^{\text {br }}$ cells conferred chemoresistance to multiple chemotherapeutic agents, further consolidating the drug-metabolizing role of ALDH1 in ovarian cancer. The present study also demonstrated that a cisplatin-resistant subclone was more enriched in ALDH1 $1^{\text {br }}$ cells, compared with its parental line. A clonal selection of populations with intrinsic $\mathrm{ALDH} 1^{\mathrm{br}}$ cells after chemotherapy is possible; however, chemotherapy may induce ALDH expression and allow the acquisition of chemoresistance in residual cancers. ${ }^{34}$ Increase in ALDH1 ${ }^{\text {br }}$ proportions in recurrent-cancer cells after heavy chemotherapy may augment the poor prognostic outcome, as evidenced in the present study and elsewhere. ${ }^{26}$ Critical elimination of this fraction of cancer cells may help improve the survival of ovarian cancer patients. Recently, several small molecules, including curcumin, piperine, sulforaphane, and quercetin, were shown to effectively target $\mathrm{ALDH}{ }^{\text {br }}$ cancer stem-like cells in breast cancers and pancreatic cancers. ${ }^{35-37}$ Targeting ALDH1 in ovarian cancer warrants further investigation.

The prognostic significance of ALDH1 in ovarian cancer remains controversial. Chang et $\mathrm{al}^{25}$ demonstrated ALDH1 as a favorable prognostic factor in ovarian cancers, which is in contrast to the expectation of ALDH1 as a potential cancer stem cell marker. Deng et $\mathrm{al}^{26}$ and Landen et al, ${ }^{24}$ however, demonstrated that serous ovarian cancer patients with high ALDH1 had poor prognosis, and recently Silva et $\mathrm{al}^{23}$ reported that patients with $\mathrm{ALDH}^{+} / \mathrm{CD} 133^{+}$cells had worse progression-free and overall survival. The inclusion of different cell types may have contributed to this inconsistent result. These three studies focused mostly on the serous type; however, the Chang et $\mathrm{al}^{25}$ study included 
Table 2. Multivariate Analysis of Clinicopathological Factors in 84 Ovarian Cancer Patients

\begin{tabular}{|c|c|c|c|c|}
\hline \multirow[b]{2}{*}{ Variable } & \multicolumn{2}{|c|}{ Recurrence* } & \multicolumn{2}{|c|}{ Survival* } \\
\hline & $\begin{array}{l}\text { Univariate analysis } \\
\text { crude HR }(95 \% \mathrm{Cl})\end{array}$ & $\begin{array}{c}\text { Multivariate adjusted } \\
\text { HR }(95 \% \mathrm{Cl})^{\dagger}\end{array}$ & $\begin{array}{l}\text { Univariate analysis } \\
\text { crude HR }(95 \% \mathrm{Cl})\end{array}$ & $\begin{array}{c}\text { Multivariate adjusted } \\
\text { HR }(95 \% \mathrm{Cl})^{\ddagger}\end{array}$ \\
\hline Age (years) & $1.02(1.00-1.05)$ & $1.02(0.99-1.05)$ & $1.05(1.02-1.08)^{\pi}$ & $1.04(1.01-1.07)^{\pi}$ \\
\hline \multicolumn{5}{|l|}{ ALDH1 expression $\$$} \\
\hline Low & 1.00 (Ref) & 1.00 (Ref) & 1.00 (Ref) & 1.00 (Ref) \\
\hline High & $1.34(0.66-2.75)$ & $1.70(0.77-3.77)$ & $2.57(1.31-5.05)^{\pi}$ & $2.43(1.12-5.28)^{\pi}$ \\
\hline \multicolumn{5}{|l|}{ Stage } \\
\hline I, II & 1.00 (Ref) & 1.00 (Ref) & 1.00 (Ref) & 1.00 (Ref) \\
\hline III, IV & $9.62(2.88-32.12)^{\pi}$ & $7.88(2.18-28.42)^{\pi}$ & $23.70(3.23-173.76)^{9}$ & $23.25(3.00-179.98)^{\natural}$ \\
\hline \multicolumn{5}{|l|}{ Grade (nuclear) } \\
\hline G1 & 1.00 (Ref) & 1.00 (Ref) & 1.00 (Ref) & 1.00 (Ref) \\
\hline G2 & $2.52(0.57-11.11)$ & $0.90(0.18-4.38)$ & $2.93(0.67-12.76)$ & $1.43(0.31-6.60)$ \\
\hline G3 & $5.69(1.30-24.96)^{\pi}$ & $2.51(0.50-12.61)$ & $5.10(1.16-22.38)^{n}$ & $3.40(0.71-16.36)$ \\
\hline \multicolumn{5}{|l|}{ Histological type } \\
\hline Serous type & $3.37(1.03-11.09)^{\pi}$ & $1.29(0.31-5.39)$ & $1.38(0.57-3.34)$ & $0.49(0.17-1.44)$ \\
\hline Other types & 1.00 (Ref) & 1.00 (Ref) & 1.00 (Ref) & 1.00 (Ref) \\
\hline
\end{tabular}

${ }^{*}$ A Cox proportional hazards model was applied.

†The analysis was adjusted for stage, nuclear grade, and histological type.

¥The analysis was adjusted for age, ALDH1 expression, stage, and nuclear grade.

$\S$ Low expression of ALDH1 regarding survival is represented as $0 \%$ to $50 \%$; high expression of ALDH1 regarding survival is represented as $>50 \%$.

"Significantly correlated with outcome $(P<0.05)$.

$\mathrm{Cl}$, confidence interval; HR, hazard ratio; Ref, reference value.

different histological types, including clear cell carcinoma, malignant mixed Müllerian tumors, transitional cell carcinoma, poorly differentiated carcinoma, and mixed-type carcinoma. Most of these tumors exhibited low expression of ALDH1 and poor prognosis. In addition, the sampling of bulky ovarian tumors and the definition of high ALDH1 may also have biased these results. Chang et $\mathrm{a}^{25}$ and Landen et al ${ }^{24}$ defined high expression of ALDH1 as $>20 \%$ cells expressing the protein, whereas Deng et al ${ }^{26}$ used $>10 \%$ as the cutoff value. Silva et al ${ }^{23}$ used a "yes" or "no" status for the expression of ALDH1 and combined this with CD133+ defined by $>1 \mathrm{CD}_{133^{+}}$cell in one section. Different stages may also bias the prognostic significance. Chang et $\mathrm{al}^{25}$ included different stages, among which the advanced stage was associated with low ALDH1 expression; however, Landen et $\mathrm{al}^{24}$ and Silva et $\mathrm{al}^{23}$ included advanced cancers, and Deng et al ${ }^{26}$ did not address stage distribution. In the present study, our analyses included different epithelial types of ovarian cancers at various stages and defined expression of ALDH1 in $>50 \%$ of cells as an independent poor prognostic factor in a multivariate analysis. ALDH1 expression alone or in combination with other stem cell markers may in the future help to stratify patients for targeted therapies.

The association between ALDH1 expression and histological type is noteworthy. Although we did not aim to draw a conclusion about the biological role of ALDH1 in the development of ovarian cancer, some speculations stemming from the association of ALDH1 expression with histological subtypes may shed new light on this subject. Our results demonstrated the presence of high ALDH1 expression in most mucinous and endometrioid cell types. Most clear cell types expressed ALDH1 at low levels. The distribution of ALDH1 expression in the serous type was heterogeneous, with two subtypes identified.
These results are supported by the only other report on this subject, that of Chang et $\mathrm{al}^{25}$ in which malignant mixed Müllerian tumors and poorly differentiated carcinoma were also reported as having low ALDH1 expression. Taken together, these results coincide with the recently proposed type I and II ovarian cancer classification, with the exception of the clear cell type..$^{2,5}$ Histologically, serous ovarian cancer exhibits morphological similarities to tubal epithelium. A tubal origin of ovarian serous adenocarcinoma was proposed recently.38 There may be different biological subtypes of high-grade serous carcinomas, as stratified using some molecular markers. ${ }^{39}$ A novel hypothesis regarding the possible origin of serous ovarian cancer in the uterus was also proposed recently. ${ }^{40}$ However, the origin of type I ovarian cancer remains elusive. As implied by the name, the mucinous type of ovarian cancer exhibits morphological similarities to the endocervical glands, whereas the endometrioid type of ovarian cancer is similar to the endometrial epithelium. Given that ALDH1 has been proposed as a stem cell marker of various origins, it is possible that $\mathrm{ALDH} 1^{\text {br }}$ ovarian cancers have a different origin, possibly in the uterus. Previous reports proposed that both ovarian clear cell and endometrioid carcinoma are associated with, and may arise from, endometriosis, ${ }^{41-43}$ which was reported recently as expressing high levels of progenitor markers, including OCT4, C-KIT, and SOX2, indicating a stem cell origin for endometriosis. ${ }^{44,45}$ However, the expression of ALDH1 in endometrial stem cells remains unexplored. The endometrial ALDH1 ${ }^{\text {br }}$ stem cell origin of certain types of ovarian cancers remains to be demonstrated.

In conclusion, $\mathrm{ALDH}{ }^{1}{ }^{\text {br }}$ enriched the stem-cell properties of EOCs, and contributed to chemoresistance and poor prognosis, but ALDH1 alone was not sufficient as a cancer stem cell marker. The combination of ALDH1 with other stem cell markers, such as CD44 and CD133, may define ovarian cancer stem cells more stringently, or may 
represent different sets of progenitor populations. Novel therapies targeting $\mathrm{ALDH} 1^{\text {br }}$ ovarian cancer cells may help improve the survival of patients.

\section{Acknowledgments}

We thank Dr. Chi-Kuan Chen, Hui-Chen Wang, and Dr. Chih-Kung Lin (National Defense Medical Center, Taipei, Taiwan, China) for expert technical assistance and Dr. Mu-Hsien Yu (National Defense Medical Center, Taipei, Taiwan, China) for administrative support.

\section{References}

1. Jemal A, Siegel R, Xu J, Ward E: Cancer statistics, 2010 [Erratum appeared in CA Cancer J Clin 2011, 61:133-134]. CA Cancer J Clin 2010, 60:277-300

2. Kurman RJ, Shih leM: Pathogenesis of ovarian cancer: lessons from morphology and molecular biology and their clinical implications. Int J Gynecol Pathol 2008, 27:151-160

3. Karst AM, Drapkin R: Ovarian cancer pathogenesis: a model in evolution. J Oncol 2010, 2010:932371

4. Karst AM, Levanon K, Drapkin R: Modeling high-grade serous ovarian carcinogenesis from the fallopian tube. Proc Natl Acad Sci USA 2011, 108:7547-7552

5. Shih leM, Kurman RJ: Ovarian tumorigenesis: a proposed model based on morphological and molecular genetic analysis. Am J Pathol 2004, 164:1511-1518

6. Fung-Kee-Fung M, Oliver T, Elit L, Oza A, Hirte HW, Bryson P: Optimal chemotherapy treatment for women with recurrent ovarian cancer. Curr Oncol 2007, 14:195-208

7. Dean M, Fojo T, Bates S: Tumour stem cells and drug resistance. Nat Rev Cancer 2005, 5:275-284

8. Zhang S, Balch C, Chan MW, Lai HC, Matei D, Schilder JM, Yan PS, Huang TH, Nephew KP: Identification and characterization of ovarian cancer-initiating cells from primary human tumors. Cancer Res 2008 , $68: 4311-4320$

9. Curley MD, Therrien VA, Cummings $C L$, Sergent PA, Koulouris $C R$, Friel AM, Roberts DJ, Seiden MV, Scadden DT, Rueda BR, Foster R: CD133 expression defines a tumor initiating cell population in primary human ovarian cancer. Stem Cells 2009, 27:28752883

10. Alvero AB, Chen R, Fu HH, Montagna M, Schwartz PE, Rutherford T, Silasi DA, Steffensen KD, Waldstrom M, Visintin I, Mor G: Molecular phenotyping of human ovarian cancer stem cells unravels the mechanisms for repair and chemoresistance. Cell Cycle 2009, 8:158-166

11. Szotek PP, Pieretti-Vanmarcke R, Masiakos PT, Dinulescu DM, Connolly D, Foster R, Dombkowski D, Preffer F, Maclaughlin DT, Donahoe PK: Ovarian cancer side population defines cells with stem cell-like characteristics and Mullerian inhibiting substance responsiveness. Proc Natl Acad Sci USA 2006, 103:1115411159

12. Hu L, McArthur C, Jaffe RB: Ovarian cancer stem-like side-population cells are tumourigenic and chemoresistant. Br J Cancer 2010, 102: $1276-1283$

13. Kusumbe AP, Bapat SA: Cancer stem cells and aneuploid populations within developing tumors are the major determinants of tumor dormancy. Cancer Res 2009, 69:9245-9253

14. Vasiliou V, Nebert DW: Analysis and update of the human aldehyde dehydrogenase (ALDH) gene family. Hum Genomics 2005, 2:138143

15. Marchitti SA, Brocker C, Stagos D, Vasiliou V: Non-P450 aldehyde oxidizing enzymes: the aldehyde dehydrogenase superfamily. Expert Opin Drug Metab Toxicol 2008, 4:697-720

16. Jones RJ, Barber JP, Vala MS, Collector MI, Kaufmann SH, Ludeman SM, Colvin OM, Hilton J: Assessment of aldehyde dehydrogenase in viable cells. Blood 1995, 85:2742-2746

17. Storms RW, Trujillo AP, Springer JB, Shah L, Colvin OM, Ludeman $\mathrm{SM}$, Smith C: Isolation of primitive human hematopoietic progenitors on the basis of aldehyde dehydrogenase activity. Proc Natl Acad Sci USA 1999, 96:9118-9123

18. Corti S, Locatelli F, Papadimitriou D, Donadoni C, Salani S, Del Bo R, Strazzer S, Bresolin N, Comi GP: Identification of a primitive brainderived neural stem cell population based on aldehyde dehydrogenase activity. Stem Cells 2006, 24:975-985

19. Ginestier C, Hur MH, Charafe-Jauffret E, Monville F, Dutcher J, Brown M, Jacquemier J, Viens P, Kleer CG, Liu S, Schott A, Hayes D, Birnbaum D, Wicha MS, Dontu G: ALDH1 is a marker of normal and malignant human mammary stem cells and a predictor of poor clinical outcome. Cell Stem Cell 2007, 1:555-567

20. Huang EH, Hynes MJ, Zhang T, Ginestier C, Dontu G, Appelman H, Fields JZ, Wicha MS, Boman BM: Aldehyde dehydrogenase 1 is a marker for normal and malignant human colonic stem cells (SC) and tracks SC overpopulation during colon tumorigenesis. Cancer Res 2009, 69:3382-3389

21. Burger PE, Gupta R, Xiong X, Ontiveros CS, Salm SN, Moscatelli D, Wilson EL: High aldehyde dehydrogenase activity: a novel functional marker of murine prostate stem/progenitor cells. Stem Cells 2009, 27:2220-2228

22. Jiang F, Qiu Q, Khanna A, Todd NW, Deepak J, Xing L, Wang H, Liu Z, Su Y, Stass SA, Katz RL: Aldehyde dehydrogenase 1 is a tumor stem cell-associated marker in lung cancer. Mol Cancer Res 2009, 7:330-338

23. Silva IA, Bai S, McLean K, Yang K, Griffith KA, Dafydd T, Ginestier C, Johnston C, Kueck A, Reynolds K, Wicha MS, Buckanovich RJ: Aldehyde dehydrogenase and CD133 define angiogenic ovarian cancer stem cells that portend poor patient survival. Cancer Res 2011, 71:3991-4001

24. Landen CN Jr, Goodman B, Katre AA, Steg AD, Nick AM, Stone RL, Miller LD, Mejia PV, Jennings NB, Gershenson DM, Bast RC Jr, Coleman RL, Lopez-Berestein G, Sood AK: Targeting aldehyde dehydrogenase cancer stem cells in ovarian cancer. Mol Cancer Ther 2010, 9:3186-3199

25. Chang B, Liu G, Xue F, Rosen DG, Xiao L, Wang X, Liu J: ALDH1 expression correlates with favorable prognosis in ovarian cancers. Mod Pathol 2009, 22:817-823

26. Deng S, Yang X, Lassus H, Liang S, Kaur S, Ye Q, Li C, Wang LP, Roby KF, Orsulic S, Connolly DC, Zhang Y, Montone K, Butzow R, Coukos $\mathrm{G}$, Zhang L: Distinct expression levels and patterns of stem cell marker, aldehyde dehydrogenase isoform 1 (ALDH1), in human epithelial cancers. PLoS One 2010, 5:e10277

27. Penumatsa K, Edassery SL, Barua A, Bradaric MJ, Luborsky JL: Differential expression of aldehyde dehydrogenase 1a1 (ALDH1) in normal ovary and serous ovarian tumors. J Ovarian Res 2010, 3:28

28. Ponti D, Costa A, Zaffaroni N, Pratesi G, Petrangolini G, Coradini D, Pilotti S, Pierotti MA, Daidone MG: Isolation and in vitro propagation of tumorigenic breast cancer cells with stem/progenitor cell properties. Cancer Res 2005, 65:5506-5511

29. Liu CY, Chao TK, Su PH, Lee HY, Shih YL, Su HY, Chu TY, Yu MH, Lin YW, Lai HC: Characterization of LMX-1A as a metastasis suppressor in cervical cancer. J Pathol 2009, 219:222-231

30. Yang X, Lin X, Zhong X, Kaur S, Li N, Liang S, Lassus H, Wang L, Katsaros D, Montone K, Zhao X, Zhang Y, Bützow R, Coukos G, Zhang L: Double-negative feedback loop between reprogramming factor LIN28 and microRNA let-7 regulates aldehyde dehydrogenase 1-positive cancer stem cells. Cancer Res 2010, 70:94639472

31. Kryczek I, Liu S, Roh M, Vatan L, Szeliga W, Wei S, Banerjee M, Mao Y, Kotarski J, Wicha MS, Liu R, Zou W: Expression of aldehyde dehydrogenase and CD133 defines ovarian cancer stem cells. Int $J$ Cancer 2012, 130:29-39

32. Agarwal R, Kaye SB: Ovarian cancer: strategies for overcoming resistance to chemotherapy. Nat Rev Cancer 2003, 3:502-516

33. Croker AK, Goodale D, Chu J, Postenka C, Hedley BD, Hess DA, Allan AL: High aldehyde dehydrogenase and expression of cancer stem cell markers selects for breast cancer cells with enhanced malignant and metastatic ability. J Cell Mol Med 2009, 13:22362252

34. Tanei T, Morimoto K, Shimazu K, Kim SJ, Tanji Y, Taguchi T, Tamaki $Y$, Noguchi S: Association of breast cancer stem cells identified by aldehyde dehydrogenase 1 expression with resistance to sequential 
paclitaxel and epirubicin-based chemotherapy for breast cancers. Clin Cancer Res 2009, 15:4234-4241

35. Kakarala M, Brenner DE, Korkaya H, Cheng C, Tazi K, Ginestier C, Liu S, Dontu G, Wicha MS: Targeting breast stem cells with the cancer preventive compounds curcumin and piperine. Breast Cancer Res Treat 2010, 122:777-785

36. Li Y, Zhang T, Korkaya H, Liu S, Lee HF, Newman B, Yu Y, Clouthier SG, Schwartz SJ, Wicha MS, Sun D: Sulforaphane, a dietary component of broccoli/broccoli sprouts, inhibits breast cancer stem cells. Clin Cancer Res 2010, 16:2580-2590

37. Zhou W, Kallifatidis G, Baumann B, Rausch V, Mattern J, Gladkich J, Giese N, Moldenhauer G, Wirth T, Büchler MW, Salnikov AV, Herr I: Dietary polyphenol quercetin targets pancreatic cancer stem cells. Int J Oncol 2010, 37:551-561

38. Levanon K, Crum C, Drapkin R: New insights into the pathogenesis of serous ovarian cancer and its clinical impact. J Clin Oncol 2008, 26:5284-5293

39. Espinosa I, Catasus L, Canet B, D'Angelo E, Muñoz J, Prat J: Gene expression analysis identifies two groups of ovarian high-grade se- rous carcinomas with different prognosis. Mod Pathol 2011, 24:846-854

40. Massuger L, Roelofsen T, Ham M, Bulten J: The origin of serous ovarian cancer may be found in the uterus: a novel hypothesis. Med Hypotheses 2010, 74:859-861

41. Ness RB: Endometriosis and ovarian cancer: thoughts on shared pathophysiology. Am J Obstet Gynecol 2003, 189:280-294

42. Viganó P, Somigliana E, Chiodo I, Abbiati A, Vercellini P: Molecular mechanisms and biological plausibility underlying the malignant transformation of endometriosis: a critical analysis. Hum Reprod Update 2006, 12:77-89

43. Wiegand KC, Shah SP, Al-Agha OM, Zhao Y, Tse K, Zeng T, et al: ARID1A mutations in endometriosis-associated ovarian carcinomas. N Engl J Med 2010, 363:1532-1543

44. Pacchiarotti A, Caserta D, Sbracia M, Moscarini M: Expression of oct-4 and C-kit antigens in endometriosis. Fertil Steril 2011, 95:1171-1173

45. Götte M, Wolf M, Staebler A, Buchweitz O, Kiesel L, Schüring AN Aberrant expression of the pluripotency marker SOX-2 in endometriosis. Fertil Steril 2011, 95:338-341 